Man Mohan

Mehndiratta, MD,

DM (Neurology), MNAMS

Prachi Mehndiratta, MD

Natasha Singh Gulati, MD

Mohammad Wasay, MD

Correspondence to Dr. M.M. Mehndiratta: mmehndi@hotmail.com

\section{HETEROGENEITY IN NEUROLOGIC EDUCATION AND CARE IN ASIAN AND OCEANIAN REGION}

The Asian subcontinent and Oceania (comprising islands in the Pacific Ocean) are home to more than $60 \%$ of the world's population. The burden of neurologic disease and sickness is thereby high and medical care is in high demand. There are many developing countries with diverse cultural, economical, political, religious, and historical backgrounds within the Asian and Oceanian region. ${ }^{1,2}$ Recently, enhanced medical care in these developing countries has resulted in greater longevity, which has increased the burden on those providing health care. The prevalence of neurologic illness has also increased and has emerged as a priority health problem. ${ }^{3}$ Most frequently reported cases in neurology are epilepsy, cerebrovascular disease/stroke, headache, Parkinson disease, neuropathies, neuroinfections, multiple sclerosis, Alzheimer disease, and other dementias.

Government and private investment in the health sector and training of medical graduates is a vital aspect of health care, as it greatly assists in provisioning services to the ever-growing population. One of the indicators of health financing that summarizes national (government and private) expenditure on health in a given year is the total expenditure on health as a percentage of gross domestic product (GDP). The figure compares the total expenditure on health as a percentage of GDP (2011) and population (2009) in some of the countries in the Asian and Oceanian region.

Poor economic growth has led to less budget allocation to the health care sector in the Asian and Oceanian regions and developing countries have a long way to go to be at the level of developed countries in provisioning of neurologic care. The gap is widened by the lack of emergency medical teams, 911 providers, and ability to treat patients with clot busters such as IV recombinant tissue plasminogen activator. Barriers to the successful delivery of health care in the Asian and Oceanian countries are high population burden, cultural and religious barriers, lack of adequate training programs in neurology, and inadequate ancillary staff such as nurse practitioners. Other obstacles include limited sustainable and basic resources - particularly in rural areas - that include staff, infrastructure, equipment, and medications. There are also practical constraints including travel on difficult terrain that hamper access to neurologic consultations.

Some of these limitations are specific to neurology. In light of these deficiencies, the WHO has launched projects to encourage health ministries worldwide to promote health education and acknowledge neurologic disorders such as stroke as a major public health problem. The WHO is also attempting to make neurologic services readily available at all levels of the health system. The table compares the neurology training, eligibility, duration, and number of neurologists/million population in some of the developed and developing countries of the Asian and Oceanian region. ${ }^{1,2}$

Bridging gaps. In our review of existing deficiencies within medical systems in the region, we have identified several necessary steps to bridge gaps in neurologic care and improve the quality of neurology training.

A powerful tool for overcoming barriers to providing adequate neurologic care is effective education and training with mandates to serve in areas that are in need. In order to guarantee the quality of trainees, there is a growing need to establish a standardized neurology residency program worldwide. Even with deficient resources, interinstitutional cooperation among the individual teaching hospitals can assist in providing adequate exposure to a multitude of neurologic diseases and add to the experience of trainee residents and fellows. If accepted by high-level hospitals, this type of integration will facilitate higher quality neurologic care. ${ }^{4,5}$

Another important hurdle is the paucity of subspecialized neurologic services. Subspecialized neurologic services provide a base for conducting directed patientoriented research and training as many neurologic disorders require highly specialized skills.

The lack of adequate training programs and absence of subspecialty fellowship training has resulted in the practice of neurology by those who are untrained in this complex field. Family practice physicians and general medicine physicians with a special interest in neurology 
Figure Comparison of total expenditure on health as a percentage of GDP (2011) and total population (2009) of some countries in the Asia and Oceanian region

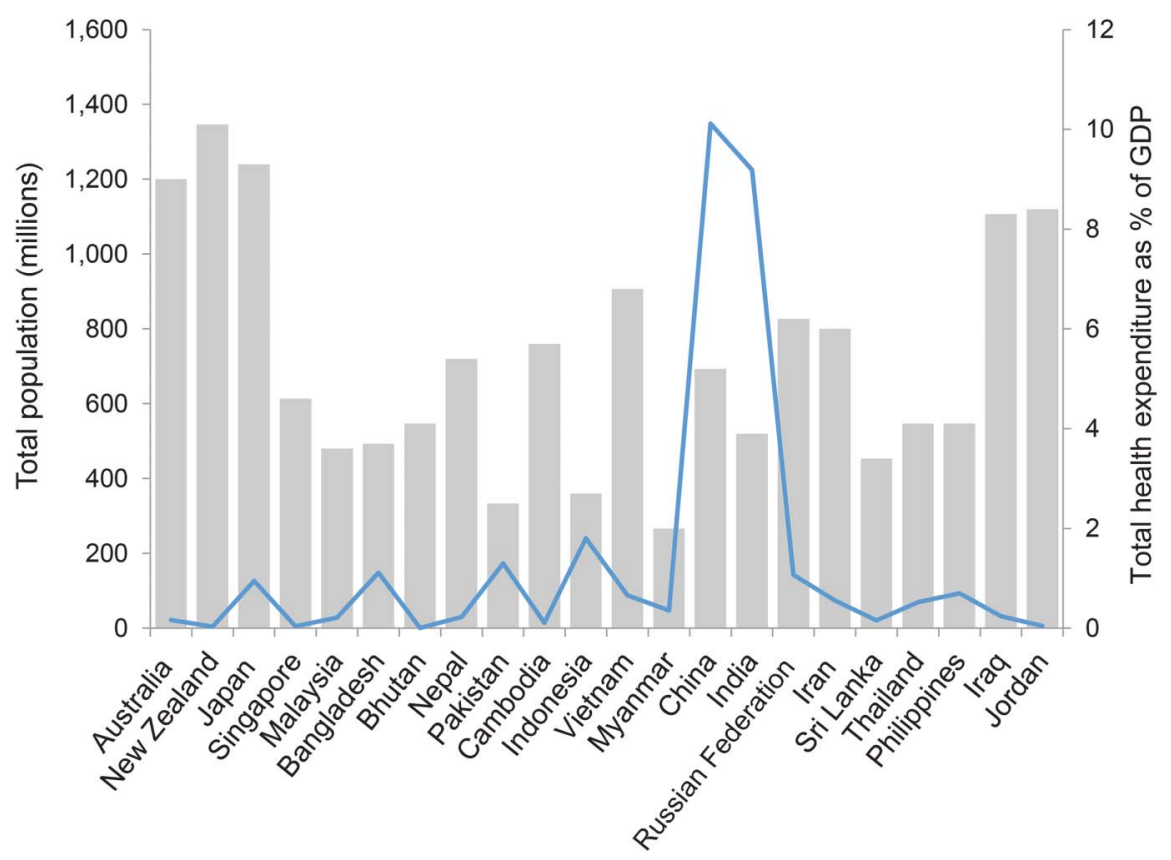

Total expenditure on health as \% of GDP (2011) (members of WHO)

Total population (2009)

${ }^{1} \mathrm{GDP}=$ gross domestic product.

or those who have passed a board or examination in neurology constitute the majority of those providing neurologic care. Dissemination of appropriate information to such providers and community neurologists through continuing medical education, conferences, seminars, and journals helps maintain best practices.
In addition to infrastructure development and allocation of resources, governments and national and regional neurologic organizations such as Asian and Oceanian Congress of Neurology, Asian and Oceanian Epilepsy Congress, Asia Pacific Stroke Organization, and others should set forth standard curriculum and

\begin{tabular}{|c|c|c|c|c|c|}
\hline Table & \multicolumn{5}{|c|}{$\begin{array}{l}\text { Neurology training, eligibility, and duration and number of neurologists/million population in some of the developed and developing } \\
\text { countries of the Asian and Oceanian region }\end{array}$} \\
\hline \multicolumn{2}{|c|}{$\begin{array}{l}\text { Country (World Bank income } \\
\text { group-developing/developed) }\end{array}$} & $\begin{array}{l}\text { Qualification awarded (name of } \\
\text { training) }\end{array}$ & Eligibility & Duration & $\begin{array}{l}\text { Neurologists/million } \\
\text { population }\end{array}$ \\
\hline \multicolumn{2}{|c|}{$\begin{array}{l}\text { Australia and New Zealand } \\
\text { (high-developed) }\end{array}$} & $\begin{array}{l}\text { Fellowship of the Royal } \\
\text { Australasian College of Physicians, } \\
\text { specialist neurology and paediatric } \\
\text { neurology (The Royal Australasian } \\
\text { College of Physicians, Adult } \\
\text { Medicine Division and Paediatric } \\
\text { and Child Health Division training) }\end{array}$ & $\begin{array}{l}\text { Initial medical qualification } \\
\text { (foundation studies) and } \\
\geq 1 \text { year postgraduate } \\
\text { workplace experience }\end{array}$ & $\begin{array}{l}6 \text { years: } 3 \text { years basic training } \\
\text { curricula (general multispecialty) } \\
\text { and } 3 \text { years advanced training } \\
\text { curricula (in detail, specialty- } \\
\text { specific) }\end{array}$ & $10.1-50$ \\
\hline \multicolumn{2}{|c|}{ Japan (high-developed) } & $\begin{array}{l}\text { Board-certified (Board examination } \\
\text { for postgraduate training in } \\
\text { neurology) }\end{array}$ & $\begin{array}{l}\text { Board certification in internal } \\
\text { medicine }\end{array}$ & $\begin{array}{l}6 \text { years: } 3 \text { years in neurology } \\
\text { training, } 2 \text { years of initial general } \\
\text { training, and } 1 \text { year of internal } \\
\text { medicine training }\end{array}$ & $10.1-50$ \\
\hline \multicolumn{2}{|c|}{ Singapore (high-developing) } & $\begin{array}{l}\text { Board-certified by Specialists } \\
\text { Accreditation Board (SAB) } \\
\text { (advanced specialist training } \\
\text { program) }\end{array}$ & $\begin{array}{l}3 \text { years of basic training and } \\
\text { passing Master of Medicine } \\
\text { (M Med) or equivalent higher } \\
\text { professional examination }\end{array}$ & 3 years neurology training & $1.1-10$ \\
\hline \multicolumn{2}{|c|}{$\begin{array}{l}\text { Malaysia (upper middle- } \\
\text { developing) }\end{array}$} & $\begin{array}{l}\text { Advanced Master of Medicine- } \\
\text { Neurology (AMMed Neurology) } \\
\text { (residency training program) }\end{array}$ & $\begin{array}{l}\text { Master of Medicine-MMed } \\
\text { Medicine Master of Paediatrics } \\
\text { MRCP with } 18 \text { months of } \\
\text { experience in medicine/ } \\
\text { pediatrics }\end{array}$ & 3 years neurology training & $1.1-10$ \\
\hline \multicolumn{2}{|c|}{$\begin{array}{l}\text { Russia (lower middle- } \\
\text { developed) }\end{array}$} & $\begin{array}{l}\text { Neurology certificate by Russian } \\
\text { Academy of Medical Sciences } \\
\text { (neurology residency training) }\end{array}$ & 2 years residency & $\begin{array}{l}3 \text { years postgraduate program in } \\
\text { neurology }\end{array}$ & $>50$ \\
\hline
\end{tabular}




\begin{tabular}{|c|c|c|c|c|}
\hline $\begin{array}{l}\text { Country (World Bank income } \\
\text { group-developing/developed) }\end{array}$ & $\begin{array}{l}\text { Qualification awarded (name of } \\
\text { training) }\end{array}$ & Eligibility & Duration & $\begin{array}{l}\text { Neurologists/million } \\
\text { population }\end{array}$ \\
\hline $\begin{array}{l}\text { Philippines (lower middle- } \\
\text { developing) }\end{array}$ & $\begin{array}{l}\text { Board-certified (residency training } \\
\text { program) }\end{array}$ & $\begin{array}{l}\text { Board certification in internal } \\
\text { medicine }\end{array}$ & $3-4$ years neurology training & $1.1-10$ \\
\hline $\begin{array}{l}\text { Thailand (lower middle- } \\
\text { developing) }\end{array}$ & $\begin{array}{l}\text { Board-certified (residency training } \\
\text { program) }\end{array}$ & $\begin{array}{l}1 \text { year rotation in internal } \\
\text { medicine program }\end{array}$ & 4 years neurology training & $1.1-10$ \\
\hline $\begin{array}{l}\text { India (lower middle- } \\
\text { developing) }\end{array}$ & $\begin{array}{l}\text { DM Neurology (higher specialty } \\
\text { postdoctoral course) }\end{array}$ & $\begin{array}{l}3 \text { years duration MD degree } \\
\text { (Doctor of Medicine)/DNB } \\
\text { (Diplomate of National Board) } \\
\text { in general medicine or in } \\
\text { pediatric medicine }\end{array}$ & $\begin{array}{l}3 \text { years (Doctorate of Medicine) } \\
\text { DM Neurology }\end{array}$ & $0-1$ \\
\hline $\begin{array}{l}\text { China (lower middle- } \\
\text { developing) }\end{array}$ & $\begin{array}{l}\text { Neurology board-certified } \\
\text { (neurology residency, National } \\
\text { Board of Neurology [license for } \\
\text { neurologist specialist]) }\end{array}$ & Doctor of Medicine (MD) degree & 3-4 years neurology training & $1.1-10$ \\
\hline Cambodia (low-developing) & $\begin{array}{l}\text { Doctorate in Medicine with } \\
\text { specialization (specialist training } \\
\text { programs) }\end{array}$ & $\begin{array}{l}\text { Bachelor of Medical Sciences } \\
\text { (BMedSc) }+2 \text { years internship }\end{array}$ & 3-4 years of specialization & Not available \\
\hline Pakistan (low-developing) & $\begin{array}{l}\text { FCPS Neurology (Neurology } \\
\text { Residency Training Programme)- } \\
\text { Pakistan College of Physicians and } \\
\text { Surgeons }\end{array}$ & $\begin{array}{l}\text { FCPS part I and } 2 \text { years of } \\
\text { training in internal medicine and } \\
\text { FCPS part II }\end{array}$ & 3 years neurology training & $0-1$ \\
\hline
\end{tabular}

Abbreviation: FCPS $=$ Fellowship of College of Physicians and Surgery.

training guidelines for those undertaking this specialized training.

Factors influencing the formulation of effective and standardized training programs are as follows:

1. Lack of personnel and infrastructure necessary for training and provision of care

2. Absence of a standardized curriculum and program design

3. Lack of standardized teaching and evaluation methods

4. Current training programs not overseen by a program director or coordinator

5. Lack of enforcement of best practice guidelines within training programs and variations in training between urban and rural areas ${ }^{5}$

Discussion. Cooperation among governmental, international, and national neurology organizations can facilitate establishment of a structured format of neurology training within the Asian and Oceanian region, thereby standardizing the quality of neurology trainees worldwide and improving quality of patient care. Simultaneously, the quality of health care infrastructure requires improvement.

\section{STUDY FUNDING}

No targeted funding reported.

\section{DISCLOSURE}

M. Mehndiratta is currently President of the Asian Oceanian Association of Neurology. P. Mehndiratta, N. Gulati, and M. Wasay report no disclosures relevant to the manuscript. Go to Neurology.org for full disclosures.

\section{REFERENCES}

1. World Health Organization. Countries. Available at: http://www.who.int/countries/en/. Accessed July 15, 2013.

2. World Health Organization and World Federation of Neurology. Atlas: Country Resources for Neurological Disorders 2004. Geneva: WHO; 2004.

3. Menken M, Munsat TL, Toole JF. The global burden of disease study: implications for neurology. Arch Neurol 2000;57:418-420.

4. Pandey S. Challenges in neurological practice in developing countries. Indian J Public Health 2012;56: 227-230.

5. Medina MT, Munsat T, Portera-Sánchez A, Durón RM, Becker CA, Holden KR; WFN Education Committee. Developing a neurology training program in Honduras: a joint project of neurologists in Honduras and the World Federation of Neurology. J Neurol Sci 2007; 253:7-17. 


\section{Neurology}

\section{Heterogeneity in neurologic education and care in Asian and Oceanian region Man Mohan Mehndiratta, Prachi Mehndiratta, Natasha Singh Gulati, et al. Neurology 2014;83;842-844 \\ DOI 10.1212/WNL.0000000000000728}

\section{This information is current as of August 25, 2014}

\section{Updated Information \& Services}

References

Citations

Subspecialty Collections

Permissions \& Licensing

\section{Reprints}

including high resolution figures, can be found at: http://n.neurology.org/content/83/9/842.full

This article cites 3 articles, 0 of which you can access for free at: http://n.neurology.org/content/83/9/842.full\#ref-list-1

This article has been cited by 3 HighWire-hosted articles: http://n.neurology.org/content/83/9/842.full\#\#otherarticles

This article, along with others on similar topics, appears in the following collection(s):

All Clinical Neurology

http://n.neurology.org/cgi/collection/all_clinical_neurology

All Education

http://n.neurology.org/cgi/collection/all_education

CME

http://n.neurology.org/cgi/collection/cme

Health systems

http://n.neurology.org/cgi/collection/health_systems

Training-international

http://n.neurology.org/cgi/collection/training_international

Information about reproducing this article in parts (figures,tables) or in its entirety can be found online at:

http://www.neurology.org/about/about_the_journal\#permissions

Information about ordering reprints can be found online:

http://n.neurology.org/subscribers/advertise

Neurology ${ }^{\circledR}$ is the official journal of the American Academy of Neurology. Published continuously since 1951, it is now a weekly with 48 issues per year. Copyright () 2014 American Academy of Neurology. All rights reserved. Print ISSN: 0028-3878. Online ISSN: 1526-632X.

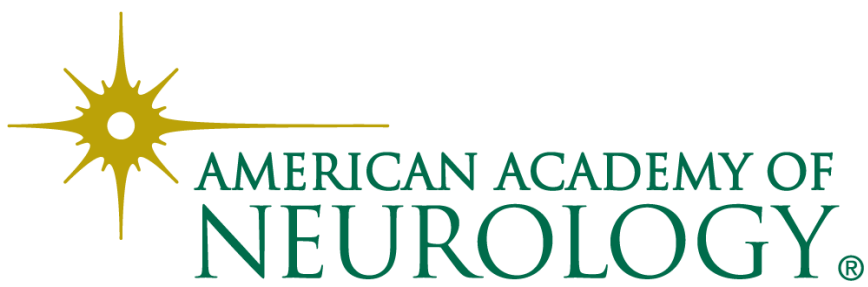

